\title{
Pat Pillar Tombs and the City: Creating WAE a Sense of Shared Identity in Swahili Urban Space
}

\author{
Monika Baumanova (D), Department of Archaeology and Ancient History, Uppsala \\ University, Engelska Parken, Thunbergsvägen 3H, 751 26, Uppsala, Sweden; Centre of \\ African Studies, University of Basel, Basel, Switzerland; University of West Bohemia, \\ Pilsen, Czech Republic \\ E-mail: monika.baumanova@uclmail.net
}

\begin{abstract}
This paper reviews published research on Swahili pillar tombs, as a specific type of tombs built of stone, by summarising records on almost fifty sites on the east coast of Africa. Dated to the 13th-16th centuries AD, the pillar tombs represented a core component of Swahili urban space. By considering their spatial setting, characteristics and comparative case studies from Africa and the Indian Ocean world, the paper reconsiders how pillar tombs might have functioned as a type of material infrastructure for creating social ties and notions of shared identity in a society that has never formally united.
\end{abstract}

Résumé: Le présent article revoit des données de recherche publiées sur les tombes à pilier swahili, un type de tombes en pierre précis, en dressant un résumé des registres portant sur près de 50 sites de la côte Est de l'Afrique. Datant du $13^{\mathrm{e}}$ au $16^{\mathrm{e}}$ siècle de notre ère, les tombes à pilier représentaient un élément fondamental de l'espace urbain de la culture swahili. En tenant compte de leur environnement spatial, leurs caractéristiques et d'études de cas comparatives provenant d'Afrique et de l'Océan Indien, l'article revoit comment ces tombes auraient pu jouer le rôle d'infrastructure matérielle permettant de créer des liens sociaux et des notions d'identité commune dans une société jamais formellement unifiée.

Resumen: Este artículo revisa investigaciones publicadas sobre las tumbas suajili en forma de pilar, como un tipo específico de tumbas construidas de piedra, resumiendo los registros de casi cincuenta sitios de la costa oriental de África. Fechadas de los siglos XIII al XVI, las tumbas en forma de pilar representaban un componente central del espacio urbano suajili. Al considerar su arreglo espacial, sus características y estudios comparativos de casos de África y del mundo del Océano Índico, el artículo reconsidera cómo las tumbas en forma de pilar podrían haber funcionado como un tipo 
de infraestructura material para crear vínculos sociales y nociones de identidad compartida en una sociedad que nunca se ha unido formalmente.

\section{KEY WORDS}

Swahili, Pillar tombs, Identity, Urban space

\section{Introduction}

In Swahili urban histories, pillar tombs have been a recurring theme, often encountered as part of the built environment in Swahili towns from the pre-colonial era (for a synopsis, see Fleisher and Wynne-Jones 2012). Having been built aboveground with durable stone material many have survived, if not always intact, to this day. Pillar tombs and other types of tombs with stone superstructures were used outside and within settlements as an integrative part of the everyday sensory experience of the living towns. Pillar tombs feature a stone pillar that makes them easily visible when they are located within the urban fabric of Swahili towns, and more monumental in terms of their size - which property may also have enabled their commemorative power and efficacy. A proposition was put forward 40 years ago in the period of early excavation projects in the region that pillar tombs constitute the sole invention of Swahili society (Kirkman 1975: 229), as they are unique in the realm of Islamic architecture. Subsequent research resituated and largely redefined early colonial and postcolonial interpretations of the nature and origins of Swahili society (Kusimba 1999a, b; Horton and Middleton 2000). However, the specific role of Swahili pillar tombs as a phenomenon of mortuary architecture that became widespread along the coast of East Africa remains unresolved.

The aim of this paper is to contribute to this debate and provide an interpretive review on pillar tombs located within settlements, based on studies that have been published about them so far. More specifically, this study addresses the questions of how and why pillar tombs were popular as an architectural feature in Swahili towns from the 13th century to the 17 th century $\mathrm{AD}$. In this article, pillar tombs are considered primarily from the contextual perspective of their structural features and spatial setting, looking at how they relate to and cross-reference the rest of the Swahili built environment, and so opening new standpoints for discussions of the use and meaning of Swahili funerary architecture. This paper makes use of records collected mostly between the 1950s and the current decade at nearly 50 sites from Somalia, Kenya and Tanzania. Some of these sites have been excavated, while others have only been surveyed, and for many there 
are no records of portable artefacts, written accounts or oral traditions associated with pillar tombs. On the basis of the review presented, it is argued that the phenomenon of pillar tombs came about and functioned as a kind of mortuary infrastructure that helped to interconnect, construct and put on display a shared identity of the people living on the coast of East Africa.

\section{The Urban Dead and Tombs in the Swahili Urban Environment}

The Swahili coast extends roughly from Mogadishu in Somalia southwards across Kenya and Tanzania to Cape Delgado in Mozambique and incorporates a number of islands in the Indian Ocean including northern Madagascar. The mortuary record consists of tombs which have a stone superstructure, and graves with no superstructure. Tombs can be found on numerous sites along this c. $2500 \mathrm{~km}$ stretch of coastline. They are part of a larger tradition of building in stone, which started to appear on the coast towards the end of the first millennium $\mathrm{AD}$ and has contributed continually to the development of Swahili urban identity (Kusimba 1999a). Swahili urban culture, and the built environment as its most visually dominating material testament, developed around Indian Ocean trade networks that linked the coast economically and culturally with the Mediterranean, Arabia, the Middle East, India and China (Pearson 1998; Beaujard 2012). Merchant activities on the coast also flourished within a broader web of wellestablished trade routes along the East coast of Africa and to the interior of the African continent (Spear 1981: 95; Pearson 1998: 67; Walz 2010; Pawlowicz 2012).

It is beyond doubt that thanks to their far-reaching trade networks, the Swahili were growing both rich and well-informed about lifeways in faraway lands and becoming cosmopolitan in outlook and orientation (LaViolette 2008). Merchants resident in these towns were exchanging African gold, wood, ivory, skins, slaves and other goods for items such as porcelain, cloth and beads from China and India (Pearson 1998; Sheriff 2006), some of which are also found in funerary contexts. Interconnected through a network of distinctive yet probably largely independent urban towns (Sinclair and Håkansson 2000), the various Swahili polities reached a climax of wealth and intensive building activity in stone between the 13th and 16th centuries AD, after which many towns declined (Kusimba 1999a) and were abandoned partly as a consequence of the Portuguese and other foreign powers entering the Indian Ocean and disrupting pre-existing trade and cultural dynamics (Pearson 1998; Beaujard 2012). Other towns fared 
rather better, however, and may have even benefitted materially from the presence of European trading partners (Vernet 2015).

A considerable portion of the wealth accumulated through trade was invested on the Swahili coast itself, especially for construction of elaborate buildings, both private and public, as well as religious, ritual and mortuary monuments. The first stone structures to be built on the Swahili coast were mosques that began to be erected around the 10th century AD (Horton 1996: 395). The urban environment gradually integrated more types of stone buildings, representing an urban society with distinctive stone architecture, which used features and items from across the Indian Ocean in new contexts (Wynne-Jones and Fleisher 2016; Wynne-Jones 2016), and reflecting the possible role of the Swahili as 'cultural brokers' on the East coast of Africa (Breen and Lane 2003: 473).

It is likely that during the first 3 centuries of the second millennium $\mathrm{AD}$, Swahili society was being increasingly exposed to the influences of cultures and small-scale immigration of peoples from around the Indian Ocean (Fleisher et al. 2015: 102). This influx of people could have affected mortuary practices as, with increased immigration, the urban dead were not brought to a place of origin for burial but interred in the towns, which might have resulted in creating new places of origin, in a manner similar to the processes known from urban Africa today (Jindra and Noret 2011: 18). This process may have brought yet more settlers, connected via kinship, from the extended families of the initial groups of urban migrants, and helped to create the concept of ummah, Muslim community, in the context of initial conversion to Islam on the coast.

To an extent, the built environment can be seen, therefore, as a material testament to how the Swahili responded to these developments characterised by inter-cultural contact, immigration and economic prosperity. The fact that a growing portion of the built environment was over time (re)constructed in more permanent material suggests that there appeared tendencies, at least among some groups within the society, to stabilise social life, to 'give structure to social institutions, durability to social networks and persistence to behaviour patterns' (Gieryn 2002: 35). This form of a more durable and costly built environment than the one known previously had to be respected or challenged by all future actors and ventures taking place in its setting.

Mortuary data for Swahili urban sites are available from the 11th century onwards. They show that the dead were buried within or outside the towns, sometimes in a very central position respective to the settlement (Fleisher and Wynne-Jones 2012). The occasional central positioning of (groups of) graves or tombs is not exceptional in the Muslim world, as we can find cemeteries in the core of cities like Basra and Kufa in present-day Iraq as well as in Murcia or Denia in mediaeval Muslim Spain (Milwright 
2010: 84). Cemeteries in Muslim urban settlements, due to their sanctity, often maintain their central location even after the city expands and other places such as orchards and workshops move beyond the town walls (Navarro and Jiménez 2007).

It seems that tombs, i.e. stone superstructures built over graves, might have represented a new component to the structuring of urban society that perhaps provided social networks with material points of reference. Tombs were constructed in isolation or in small clusters (usually of 2-6), outside or inside the residential areas. Generally, we can say that those tombs located within settlements can be found in association with residential buildings (e.g. Kirkman 1952; Horton 1996: 75), next to or near mosques (e.g. Sassoon 1982), on open spaces among buildings (e.g. Freeman-Grenville 1962) or in the open courts of larger buildings (e.g. Kirkman 1963) and that they can be distinctly monumental. The new practice of building tombs must have had social and economic implications beyond changing the appearance of Swahili towns. Elaborate funerals in Africa have been known to increase the circulation of money (Jindra and Noret 2011: 23), and while representing a major expenditure for some, it created economic opportunities for others, such as masons and stone carvers.

The earliest tombs probably appeared in the 11th century as at Kaole (Kirkman 1974; Chami 2002). However, the first pillar tombs, i.e. tombs where the superstructure features a pillar, are dated to the 13th century $\mathrm{AD}$ and later as at Shanga (Horton 1996: 13, 395) and Kilwa Kisiwani (Chittick 1974). Tomb-building appears after mosque-building in stone had begun, and on many sites, it also post-dates the beginnings of the use of stone in house construction or is roughly coeval with it (Fleisher et al. 2015: 108). Interestingly, all the known earliest tomb sites are on islands (e.g. Chittick 1984), although this may be coincidental, respective to the survey/excavation possibilities or preferences at the time of research. Given the fact that tombs could have been reused in subsequent periods, as at Songo Mnara (Fleisher 2013) and that excavations have not always yielded suitable material for reliable dating, it is possible that, especially for older research, the established dates are not accurate. Nonetheless, it is apparent that once the Swahili started building tombs, the variety in their appearance, including pillar tombs, seems to have increased rather rapidly within a century or two, and they remained in fashion throughout the 'golden era' of Swahili stone building up to the 16th century on sites from Somalia to Tanzania (Chittick 1963; Kirkman 1964; Chittick 1970; Sanseverino 1983; Horton and Clark 1985).

Throughout the last two decades, archaeologists have become aware that stone architecture is an element that has been singled out perhaps too many times as constitutive of Swahili urbanism, drawing attention to a great number of wattle-and-daub structures and open spaces (Fleisher and 
LaViolette 1999) and a range of other themes that should be taken into account including the wider hinterlands of the towns (Pollard et al. 2012). Considering the representation of stone architecture in mortuary contexts, no doubt the same bias exists. On many sites for which there are no graves without superstructures mentioned in the records as at Omwe or Kiunga in Kenya (Wilson 1978: 19-26, 30-39), it is likely that many graves must have been present apart from the tombs recorded there, given the size of these sites. More tombs have also been excavated compared to simple graves, where an aboveground structure is absent.

As they are built of stone, on some sites tombs represent the only features that survive on the surface-as systematic surveys along the coast have demonstrated (e.g. Wilson 1980: 155-159). On other sites, they appear in spatial proximity to other structures as a component of complex, stone-built townscapes. Conversely, in some sections of larger sites they might seem isolated, perhaps due to the fact that they were built among wattle-and-daub structures that did not survive aboveground (for numerous examples from Kenya, see Wilson 1978, Wilson 1980). Considering Shanga (which has been investigated by large scale, open-area excavation), for example, the proportion of the buried population that were given tombs is estimated to have been no more than around 3\% of the deceased over the whole period of occupation (Horton 1996: 75). To borrow the expression used by Fleisher and LaViolette (1999), the 'hidden majority' in mortuary contexts might then be even larger than is the case with residential structures.

\section{History of Research}

The Oxford Handbook of The Archaeology of Death and Burial (edited by Tarlow and Stutz 2013) barely mentions mortuary contexts on Swahili sites, and while not wishing to single out this publication, this omission does serve to highlight that the kind of in-depth research undertaken in many other regions of the world is largely missing from sub-Saharan African archaeology (Edwards 2013). Nonetheless, given the early researchers' interest in monumental archaeological heritage, the study of Swahili tombs has a relatively long history in East Africa. Early studies are best represented by examples from Gede, Mnarani, and Kaole (Kirkman 1958, 1960, $1963,1974)$ among others, where the first systematic excavations of tombs were conducted soon after the end of World War II. This research was later complemented by the study of their characteristics and stylistic development as part of a wider study of Swahili architecture by Peter Garlake (1966). Garlake's interests were predominantly focused on mosques along the Swahili coast as these structures survived at many sites, but he also 
commented on, illustrated and analysed the tombs found in association with mosques.

More data concerning pillar tombs were brought to light as research intensified with work on sites where they are represented, like Jumba la Mtwana (Sassoon 1980; Kusimba 1993), Kilwa Kisiwani in Tanzania (Chittick 1974), the Lamu archipelago in Kenya (Chittick 1967) and the most comprehensive survey of Swahili sites along the coast of Kenya by Thomas Wilson (Wilson 1978, 1979, 1980). During this era of formative research on the Swahili coast, archaeologists focused on describing the architecture of the tombs, including the use of monumental features such as domes, pillars, decorative panelling and inscriptions, sometimes noting wherever these features reflected similarity with what had been encountered on the remains of mosques and houses (see Wilding 1988 for an early synthesis). This phase of research concluded in the early 1990s was undertaken alongside changing approaches to Swahili archaeology more generally, during which linguistic, ethnographic, historical and archaeological evidence were brought together to redefine earlier assumptions about the Near Eastern origins of Swahili culture.

Gradually, a new picture of Swahili society and its material representations including architecture as cosmopolitan yet conclusively African in origin and nature emerged (Kusimba 1999a; Kusimba and Kusimba 2003). In the 1980s, for example, research at Shanga contributed new data on Swahili mortuary contexts arising from the detailed recording of a number of tombs and graves, both individually standing and on cemeteries (Horton 1996). Mark Horton was perhaps the first scholar to go beyond a purely descriptive approach by focusing on systematic analytical conceptualisation of the different burial contexts at Shanga. He argued, in particular, that the mortuary spaces at Shanga were active in renegotiations of power relationships between the respective clans that were settled in the different quarters of the town, suggesting similar spatial divisions for the cemetery (Horton 1996: 71-76). The symbolism of the form of mortuary architecture, its decorative features and social references were also explored in several studies considering both archaeological and ethnographic data (Abungu 1994; Kusimba 1999b).

Research over the last decade or so has been characterised by advances in theoretical thinking as well as new data being obtained. In this vein, Fleisher and Wynne-Jones (2012) have considered the spatial practices evident at Songo Mnara in Tanzania. Combining their work on the role of open spaces within Swahili settlements with linguistic and ethnographic evidence, they argue for the existence of an underlying yet important social logic to the central positioning of one of the cemeteries at Songo Mnara. In particular, they suggest this functioned not only as a resting place for the dead but was used in processions, in regular commemoration of ances- 
tors, and even served as a daily visual reminder on one's place in society (Fleisher and Wynne-Jones 2012). Looking at tombs specifically, Gensheimer (2012) has also provided an overview on what is known about the stylistic features of Swahili mortuary architecture and its past roles. Most recently, Meier (2016) has focused on the later local re-interpretations of the pillar tombs as places representing the past yet still active in negotiations of social relationships.

This paper examines the data published on nearly fifty sites with tombs including known case studies of sites pillar tombs. Given the history of non-systematic research on the coast, the data presented (Table 1) are by no means exhaustive. They have been recorded during large-scale excavation projects (such as at Gede, Shanga, and Songo Mnara), as well as during non-intrusive single-season surveys (such as She Jafari and Kiunga). The data are certainly more complete with regards to Kenya, where Wilson undertook his invaluable research along the entire Kenya coast (Wilson 1978, 1980). In Tanzania, research has followed a different path, focusing more on individual sites rather than extensive regional surveys along the coast. For Somalia there are few records of Swahili sites generally given the long-term unfavourable political situation, the best survey and sample excavations still being those conducted by Sanseverino (1983; although see also Chittick 1982 and Pouwels 1987). Overall, there appears to be no correlation between the presence/absence of certain kinds of pillar tombs within a site, but it does seem that variability in their appearance within each townscape was highly pronounced.

\section{Characteristics of Tombs on the Swahili Coast}

Swahili tombs are typically described as monumental and built of stone; but both statements and their connotations need closer consideration. The material used for building the tombs was the same as for mosques and houses, i.e. 'coral rag set in mortar of lime and earth, with surfaces plastered and cut coral employed for fine edges' (Wilson 1979: 33). The use of the same material meant that the architecture of the tombs was hence interlinked with the fabric of the living urban environment of the city, bridging the gap between what we today might classify as residential and mortuary architecture. The tombs could be classified as monumental as they must have stood out in their cultural context among the majority of graves (for comparison see Hildebrand 2013: 160), and exceeded their 'practical' function in scale and elaboration (Trigger 1990: 119), although investing in building a tomb might have been a social necessity with very tangible implications for the living. 


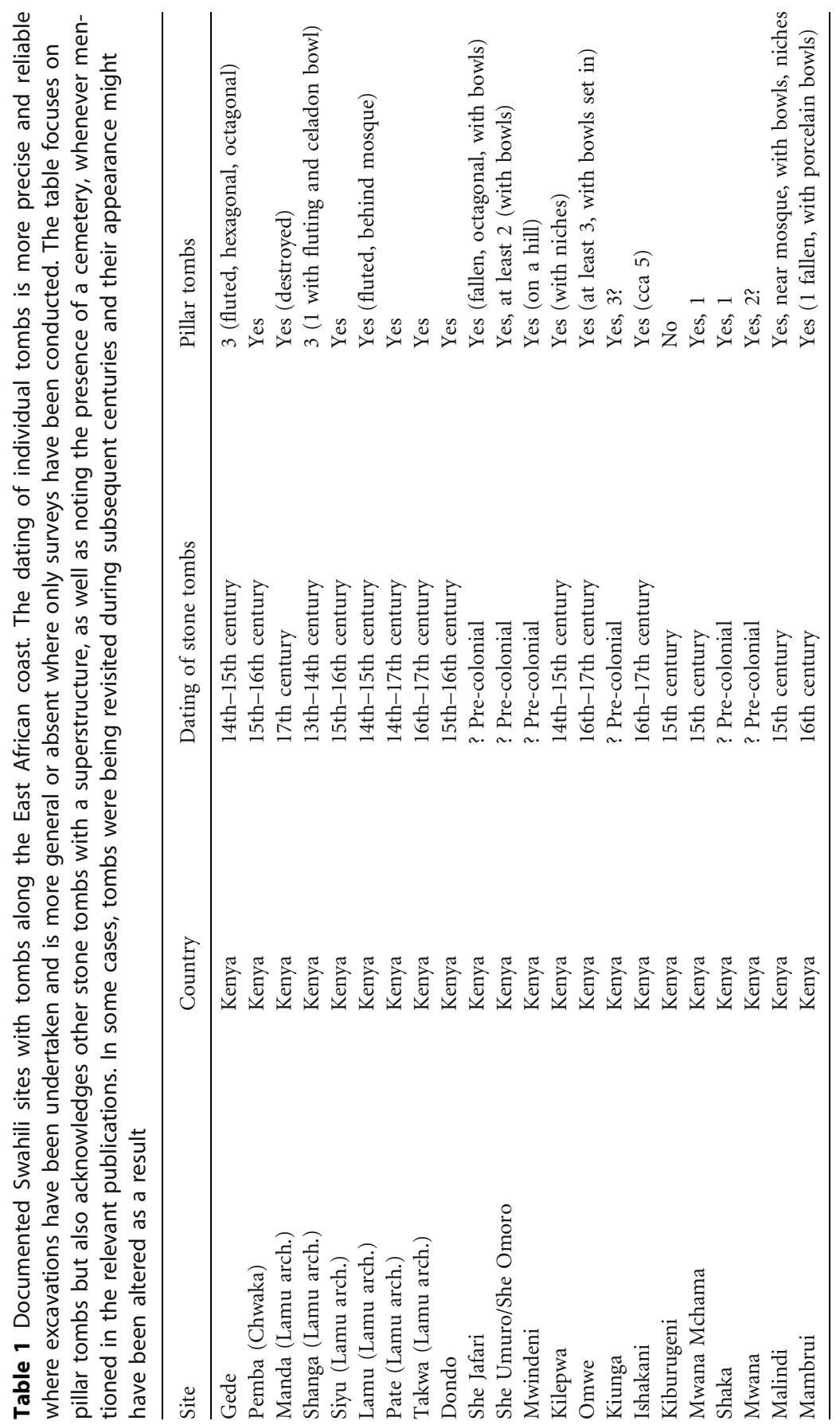




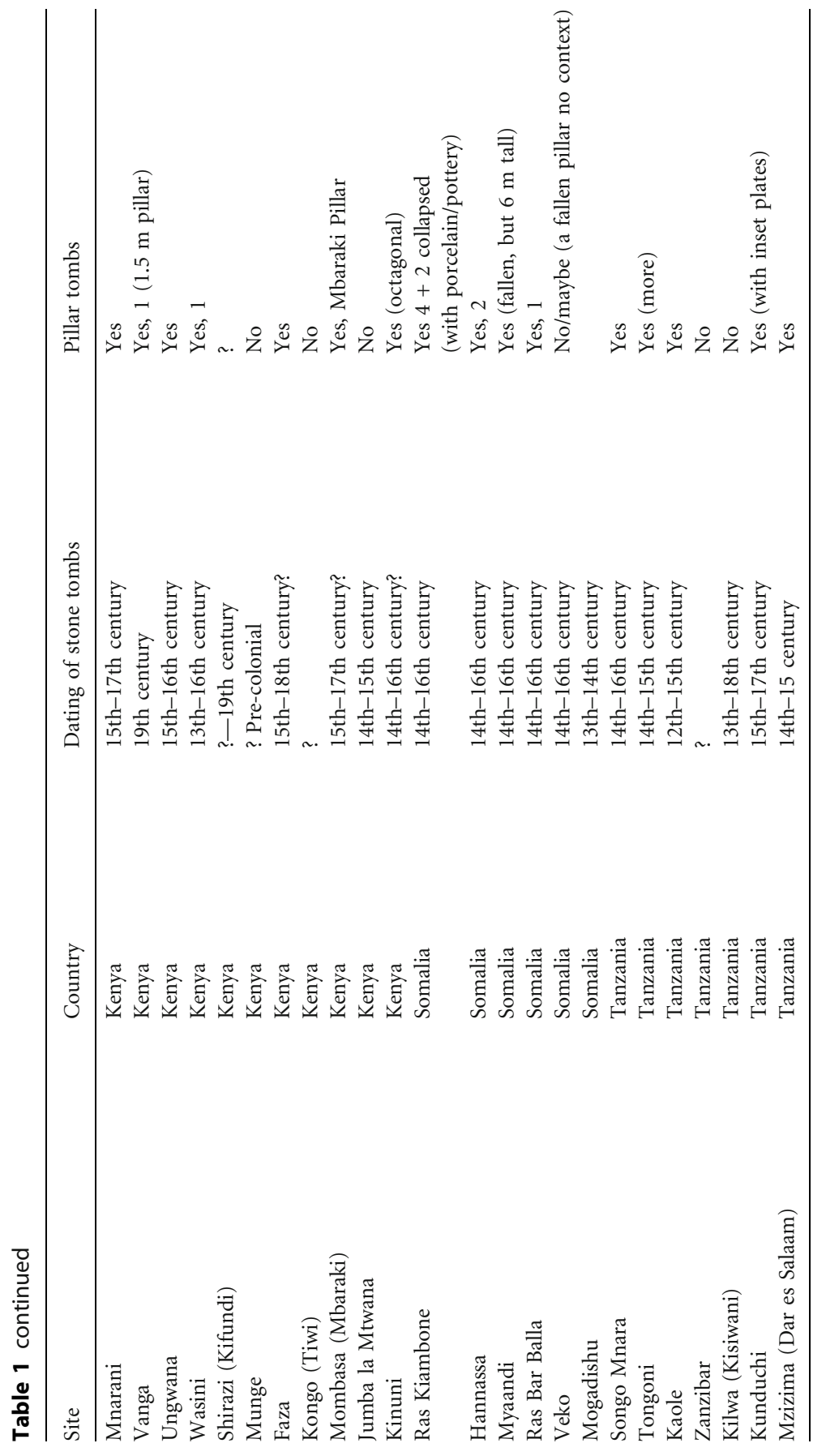




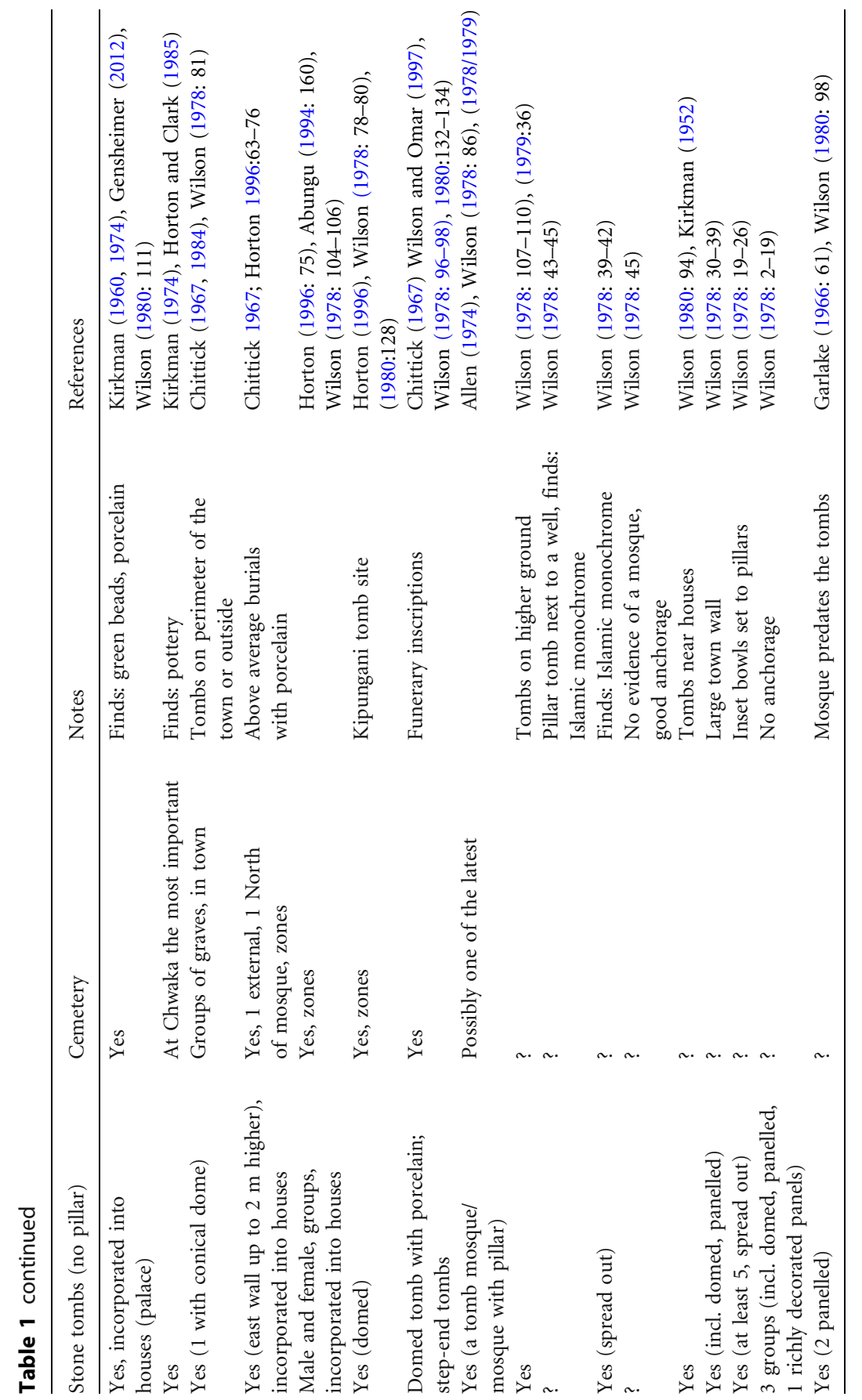




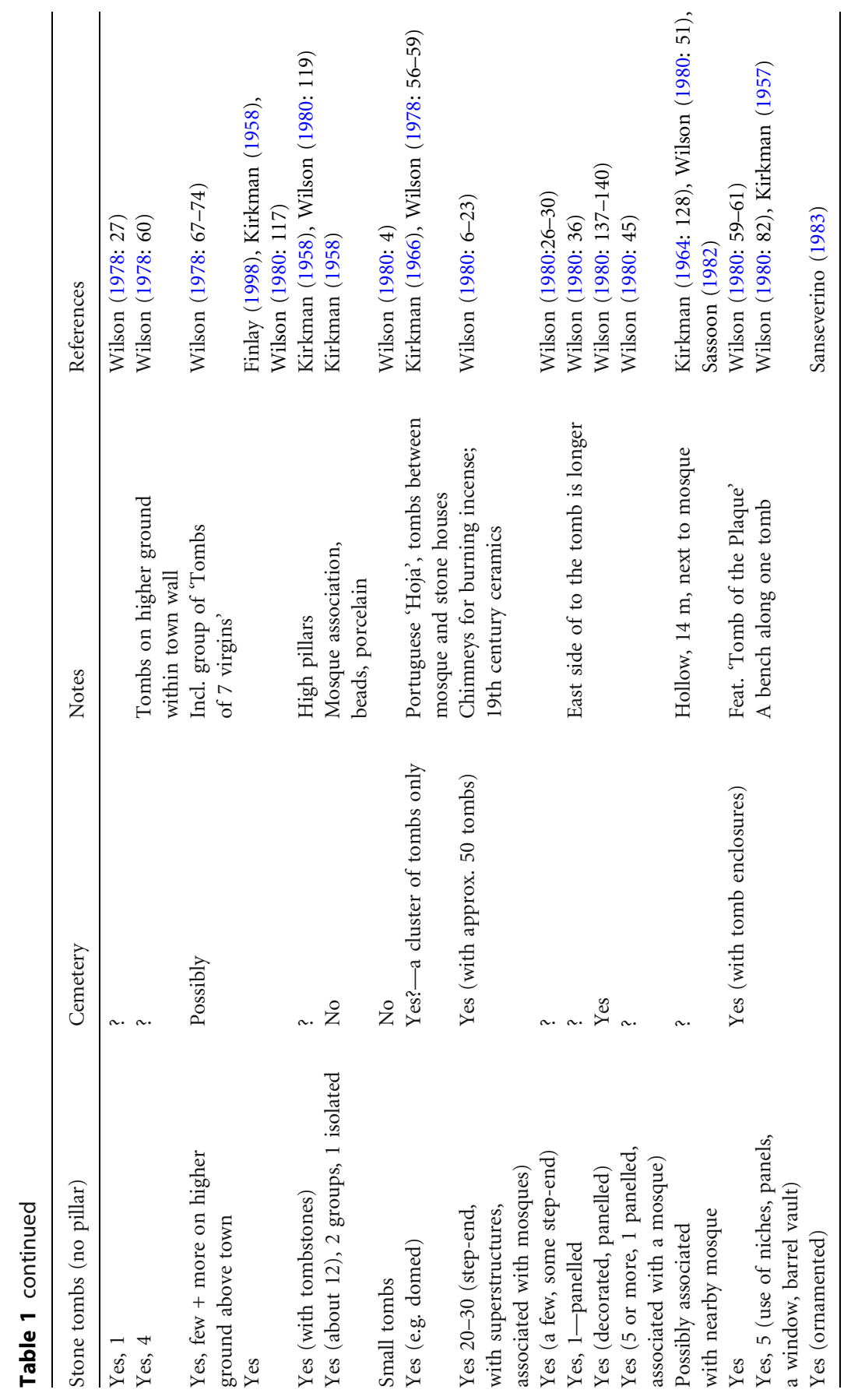




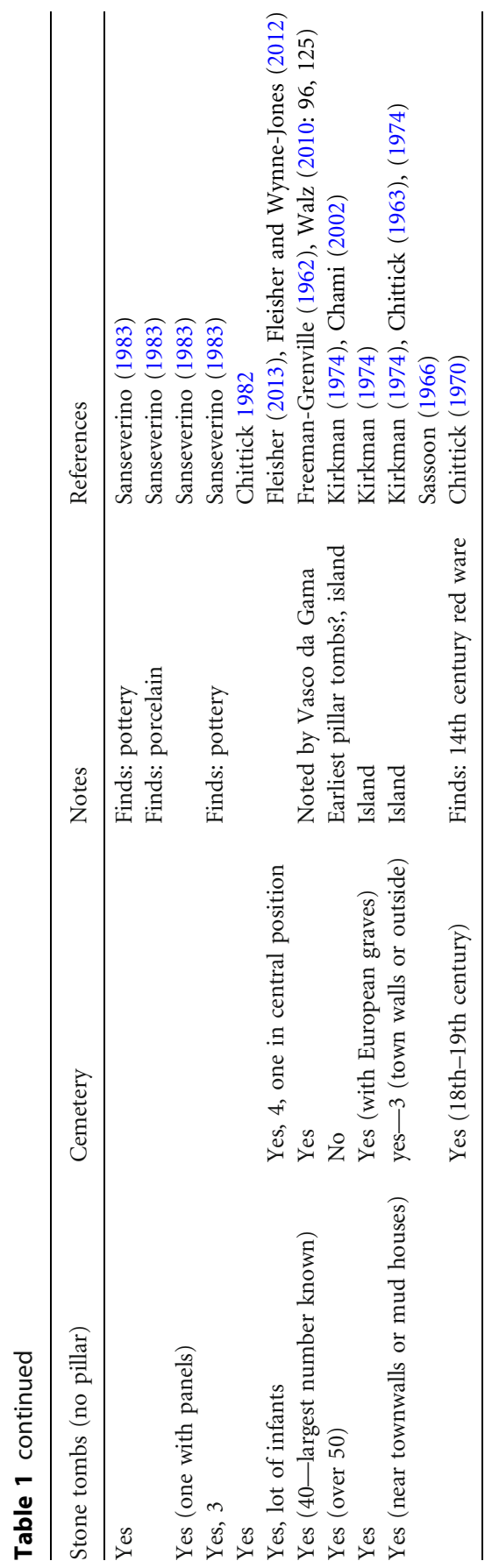




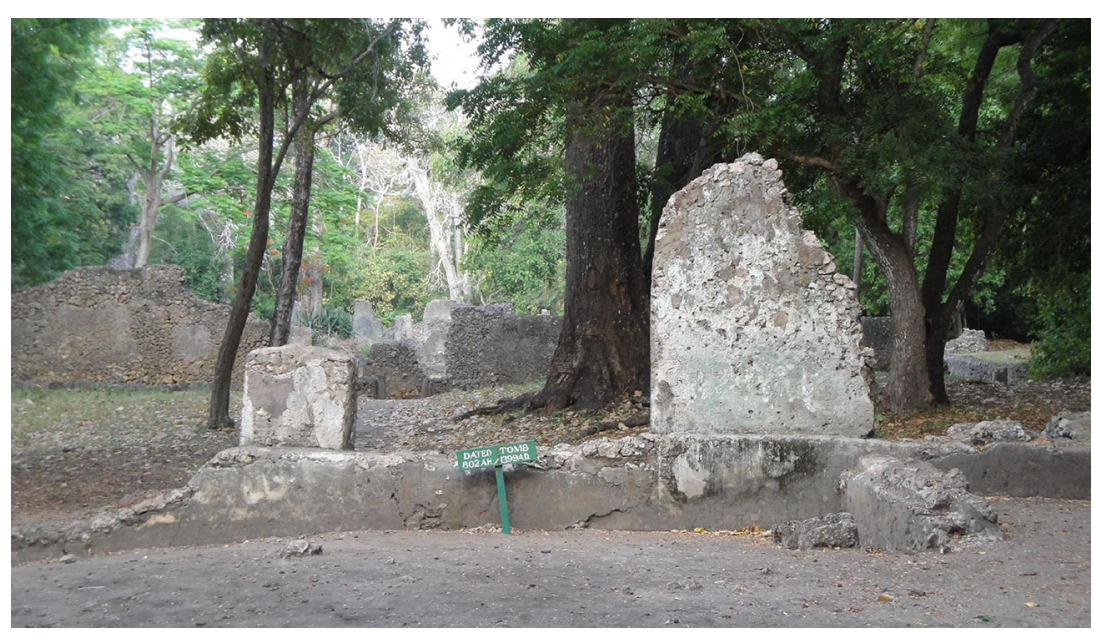

Figure 1. The remains of a solitary standing Swahili tomb in an urban context, 'the Dated Tomb' from the site of Gede, Kenya. (c) The Zamani Project, reproduced with permission

The tombs of the 13th-17th centuries were usually composed of a main aboveground cenotaph, underneath which the deceased was buried (see, for example, Figure 1). From early on, Swahili burials show compliance with general Islamic mortuary customs, such as their orientation to the north or north-east-usually between $345^{\circ}$ and $35^{\circ}$ which in East Africa is the direction towards Mecca (for example, see Wilson 1978, 1980), and the interment of the body without a coffin on its right side (Insoll 2003: 17), often so as to face the qibla of a nearby mosque (Milwright 2010: 133). Grave goods are rare, which complies with the broader Islamic practice guided by the Hadith that also states that there should be no grave marker (Milwright 2010: 131). Nevertheless, there have developed many regional traditions and variety in building Muslim tombs, especially outside the Near East (Insoll 2003: 17), and only a few African Islamic customs have been known to take directions from the Hadith (Jindra and Noret 2011: 28). It is possible that cloth was used as a type of grave goods in mortuary contexts, as it was a significant import to East Africa from India throughout the whole documented history (Pearson 1998), but no textiles have been recovered archaeologically owing to preservation factors. Based on case studies from the Lamu archipelago and recorded oral traditions, stone tombs were probably not reserved for individuals of a particular gender or age (also see Fleisher and Wynne-Jones 2012).

The orientation of the tomb may not respect the orientation of the interred body, because superstructures were often added long after the body was buried (Fleisher and Wynne-Jones 2012: 195). The commonest 


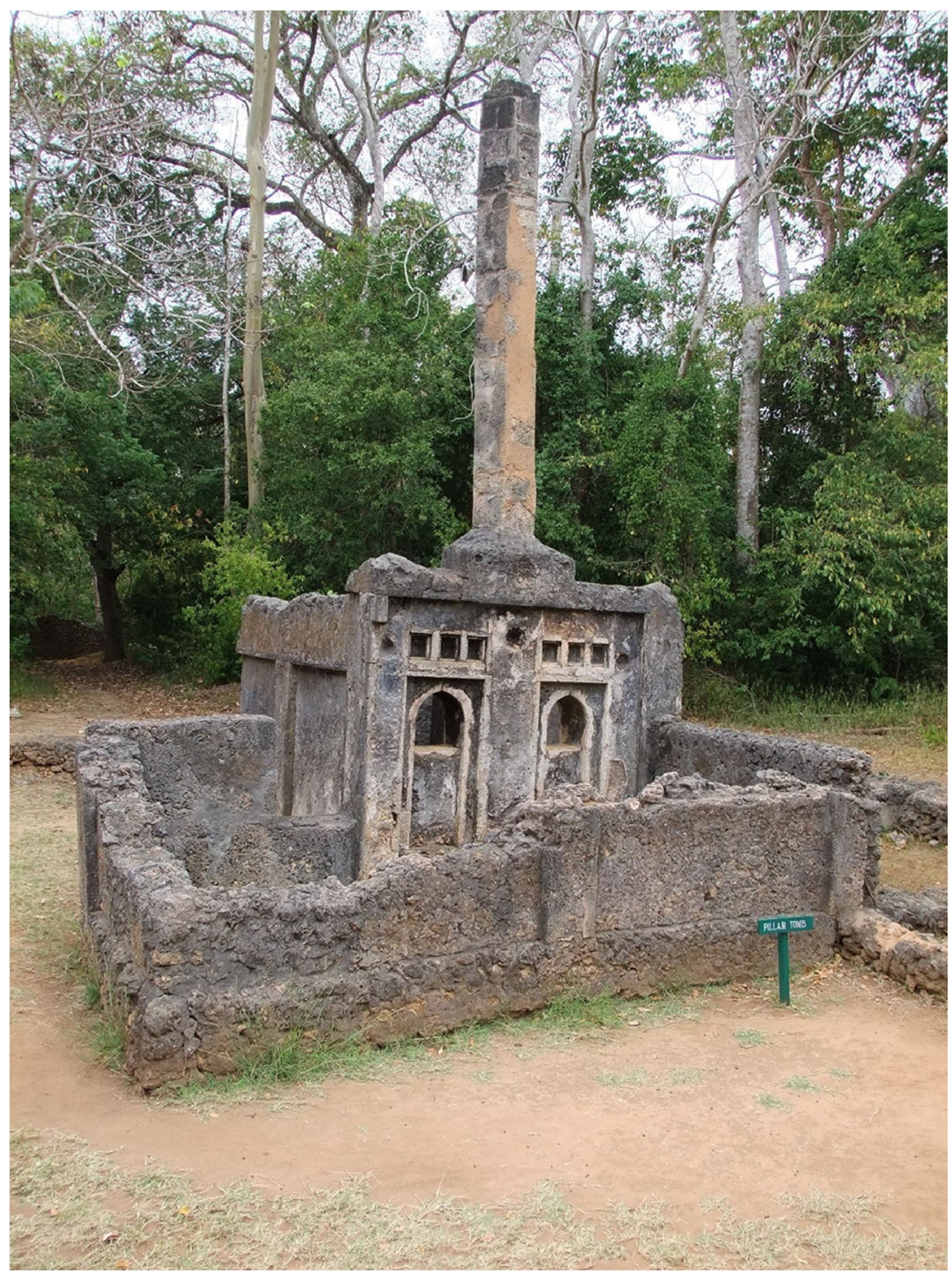

Figure 2. A pillar tomb with carved decorations, the site of Gede, Kenya. (C) The Zamani Project, reproduced with permission

aboveground structure features a four-sided low wall, generally rectangular in plan, although there are also some square examples-e.g. at Kongo, also known as Tiwi, in Kenya (Wilson 1980: 45). One or more walls of the tomb can be decorated or panelled (Figure 2). A particularly common style 


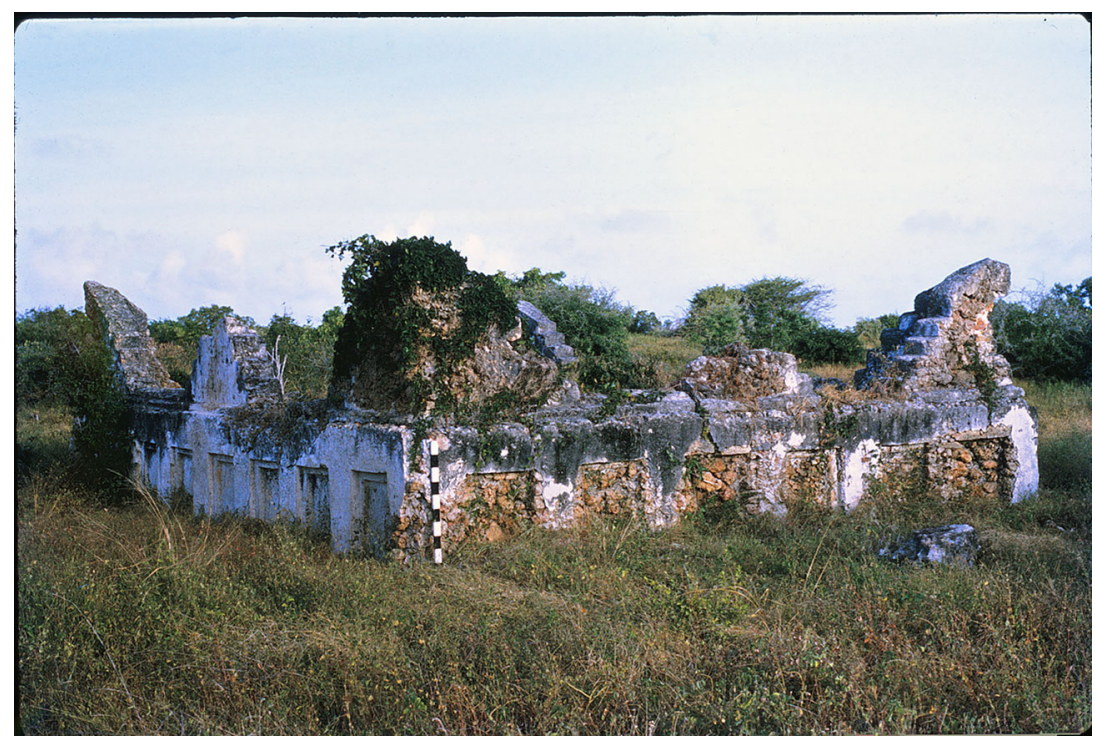

Figure 3. Step-end tomb, Kiunga, date not known. Photograph Neville Chittick (C) BIEA, reproduced with permission

is the so-called step-end tombs, which, as the name suggests, have surrounding walls cut in a step-like fashion (Figure 3). All walls might be richly decorated with carving and inscriptions-e.g. Ishakani in Kenya (Wilson 1978: 2-19), but this is rather rare. Tomb inscriptions, if present, communicate gender, status or occupation of the deceased; they can make claims of ownership, origin and ethnicity (Insoll 2003: 237). The most prominent decoration is usually reserved for the main wall of the tomb, which is generally the eastern side (Wilson 1979: 35; Gensheimer 2012). This might feature one to three elements, such as shallow decorative niches, panelling, inscriptions, a series of recessed surfaces or niches for the display of imported Chinese porcelain or incense burners (Wilson 1979: 35 ), and it is also where a pillar is positioned if there is one.

\section{Characteristics of Pillar Tombs}

Pillar tombs might feature inscriptions, porcelain bowls, niches or carving on the pillar itself. The use of imported ceramics such as Chinese porcelain for permanent insets adorning the pillar was probably the most common practice (Kirkman 1957; Sassoon 1966; Finlay 1998). Some pillar tombs had 'chimney-like' features that were probably used for the burning of 


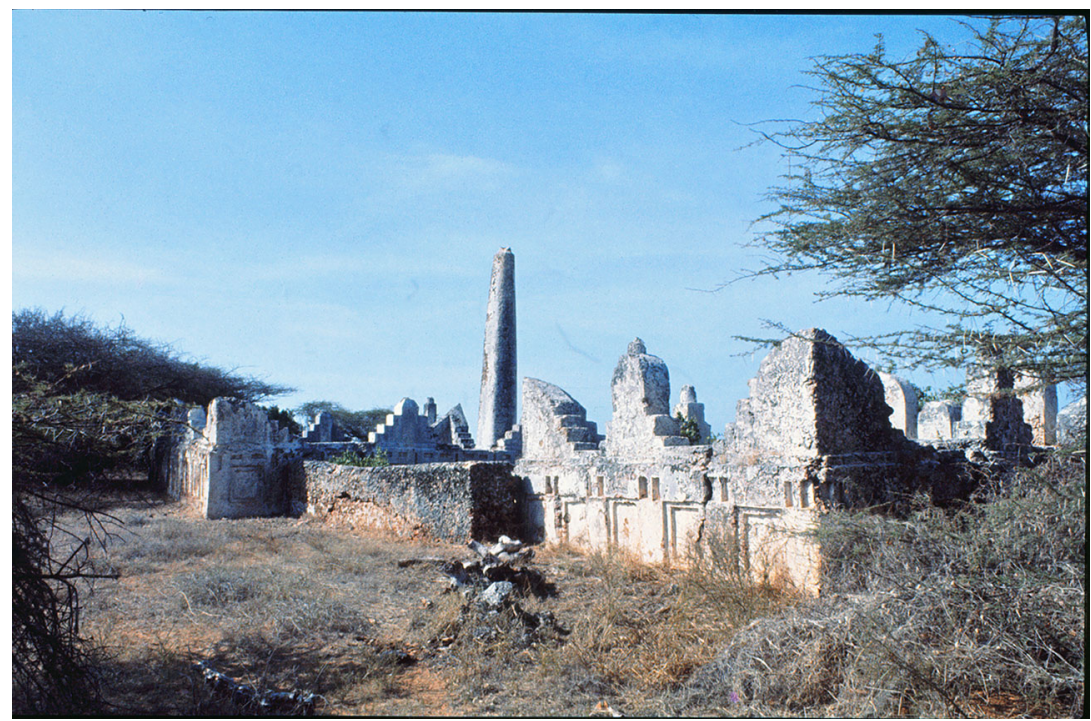

Figure 4. Tombs with round pillar in the middle, Ishakani, no date. Photograph Neville Chittick (C) BIEA, reproduced with permission

incense-e.g. at Wasini, Kenya (Wilson 1980: 6-23). The pillar might be of various heights, but usually it is between 3 and $8 \mathrm{~m}$ tall. The tallest known pillar (now collapsed) was probably in Mambrui, Kenya, and might have been 15 metres tall (Kirkman 1964: 128). The pillar can be round, square, polygonal or fluted (Figures 2, 4). Interestingly, if more than one pillar tomb is present at a single site, then no pillars seem to be of same design-e.g. Gede and Omwe in Kenya or Ras Kiambone in Somalia.

The earliest pillar tombs might have been built around the 13th century, 1 or 2 centuries after the broader phenomenon of tomb-building appeared (Horton 1996: 395). For the North Kenya coast, out of 75 tombs that Wilson recorded, $22 \%$ featured a pillar (Wilson 1979: 36). It is difficult to tease out any periodisation regarding the popularity of certain types of decorative features, but there might have been some general trends. Wilson suggested that all types of pillars were in use by the 15th century at least, the period of 15 th and 16th century representing the greatest variety and popularity of their use (Wilson 1979: 36). Sheriff argued that porcelain replaced carved decoration on a larger scale in the 17th or 18th century (1987: 15), but even in the 16th century Portuguese imitations of porcelain were popular in mortuary contexts (Kirkman 1958; Garlake 1966: 56; Abungu 1994: 155). Wilson held that pillar tombs disappeared on a large scale in the early 17th century (1979: 36), and Allen ascribed this develop- 
ment to the increasing orthodoxy of society (Allen 1974: 115). However, on most sites with tombs dating is uncertain, because many of these sites were reused for centuries for ritual and commemorative offerings and recorded archaeologically only on the basis of surface survey (Wilson 1980: 6-23; Chami 2002). Hence, surface finds are mostly associated with these later periods-e.g. at Mwana or Kiunga in Kenya (Wilson 1978: 19-26 and 67-74).

The variety of designs, which is more pronounced when more pillar tombs occur at a site, suggests that differential design itself might have been important. If some of the pillar tombs were actively used by the society long after they had been built, as resting places of local saints or a town founder, in some cases at least to the 19th century as e.g. at Shirazi (Wilson 1980: 26-30), then where did the phenomenon come from?

\section{The Purpose and Meaning of Pillar Tombs}

By the 13th century, which is the time when pillar tombs appear, the Muslim practice of honouring graves of holy men became widespread. Yet in a number of Islamic regions across Africa where monumental tombs are known, they typically take the form of a domed structure or qubba. These have been recorded, e.g. among the Beja in Sudan from 13th-14th century (Hinkel 1992: 77), Egypt (Kuban 1985: 33), the central and northern Nile Valley in Sudan (e.g. El-Zein 2010; McHugh 2016) and in Eritrea (Insoll 2003: 52). Domed monumental tombs are found in urban contexts in other East African communities such as among the Merina of inland Madagascar, where they are used for making social claims of ancestry and land ownership (Bloch 1971: 107-112). These were known places of pilgrimage and commemoration (Insoll 2003: 102) and similarly to Swahili pillar tombs, e.g. at Mbaraki (Sassoon 1982) and Takwa (Wilson 1978/ 1979), long venerated as places of spiritual power and source of protection. As Insoll (2003: 180) notes, although such practices are not generally present in orthodox Islam, they are common in many Muslim communities around the world. Although domed tombs were also known on a number of sites on Swahili coast, we may ask why specifically the use of pillars became more widespread here.

Allen argued that pillar tombs represent the remnants of a pre-Islamic pillar cult (Allen 1974: 115). In communities geographically close to the Swahili, we might trace the use of pillars in mortuary contexts, e.g. on the Islamic sites in Madagascar such as Vohemar (Insoll 2003: 197), Yemeni sites of southern Arabia (Ho 2006: 14) and among the non-Muslim Mijikenda of inland Kenya who marked burials with small pillars (vigango) (Mutoro 1994: 136; Udvardy et al. 2003). Further back in time, stone 
monoliths of varying size often feature in Pastoral Neolithic (c. 4800-1200 BP) burial cairns and other forms of 'megalithic' complexes around Lake Turkana and elsewhere southwards along the central Rift Valley and its margins (Davies 2013; Grillo and Hildebrand 2013). Although their relationship to Swahili-era practices is fairly tenuous, they point to the existence of a long-standing regional tradition that might have resonated with the more northern, pastoralist groups that some researchers argue contributed to the early formation of a Swahili identity.

Elsewhere in the region, in highland Madagascar, standing stones were used as manifestation of local ancestry and history of social interactions and transactions (Crossland 2001). Other researchers have drawn parallels with the phallic monuments of the Horn of Africa (Kirkman 1964; Insoll 2003: 67), and these are also known from mortuary contexts, e.g. at Tutu Fella and Tututi in South Ethiopia and Aw-Barkhadle in Somaliland (Mire 2015: 104-105); however, these pillars are usually smaller than those found in Swahili contexts and more numerous occurring across the entire burial ground, and not just used selectively for specific individuals. Also, they are not found in the same kind of urban context as on Swahili sites. Monumental carved stelae/monoliths were widespread as markers of elite burials in Aksum in Ethiopia (Phillipson 2003). Commemorative carved stelae have also been recorded in Islamic West Africa, most prominently from 12 th to 14 th century Gao in Mali, which were imported over long distances from what is today Spain (Insoll 2003: 235; Milwright 2010: 132). Inspirations outside Africa might have included pillar designs known from the Indian subcontinent (Lewcock 1976) and western Indian monuments or Persian tombs with towers (Wilson 1979: 41).

If the key factor in building early pillar tombs was influence from north-east Africa, inland areas along the Rift Valley, the wider Red Sea zone and/or via the Indian Ocean, and considering the fact that the Swahili traded along the coast, then perhaps we could expect the earliest pillar tombs to be found on the northern of the Swahili coast and later spreading further south. This is not the case, and since the first pillar tombs appear more or less simultaneously in Kenya and Tanzania (Kirkman 1974; Chami 2002), they more likely represent a local coastal development that quickly gained popularity, perhaps building on earlier efforts to achieve greater monumentality and visibility for the mortuary structures. This is further supported by the fact that early tombs, such as at Shanga, seem to have featured small and simple superstructures, which grew gradually grander and more complex (Horton 1996: 71-76).

For deriving the origins and purpose of pillar tombs, some authors focused on the later function of this mortuary architecture and mostly concluded it hinged on commemorative practices, claims of hereditary succession (Wilson 1979: 34), a group's ancestry and ownership of land 
(Kusimba 1999b: 330). The use of imported pottery inserted into the pillars, and general adorning of tombs, might be seen as a variation on the display of wealth and commemoration of ancestors, which also has parallels with other Islamic societies in East and Northeast Africa, e.g. on the Dahlak Islands off the Eritrea coast where domed tombs with inscribed superstructures, decorative rugs and use of incense burners are known (Insoll 2003: 52). However, insetting imported ceramics onto the pillars might also be seen as a reference to having connections with foreign lands. Parallels can be found in the way Islamic pottery was used, for instance, as inserts in the facades and pulpits of Christian churches in Italy and Greece from 11th to 15th century (Milwright 2010: 165). The importance of tombs as places for veneration of ancestors has been argued to more or less overlap with assertions of power (Horton 1996: 72-76; Wynne-Jones and Fleisher 2010), and the Muslim tradition of worshipping places connected with particular saints and social leaders (Glassman 1995). Developing these ideas, Meier (2016: 151) has argued that they served to proclaim the Swahili as participants in the practice of urban Islam within the wider Islamic world. To begin to answer why pillar tombs appeared later than other tombs and yet became so widespread on the coast, we can at least infer that in the 13th century there must have arisen a social need for this kind of material expression.

Adopting an intensive approach that looks in more depth at individual sites and analyses their specific context, Fleisher and Wynne-Jones (2012) analysed a cemetery with tombs at Songo Mnara in context with the past use of open spaces, using chemical soil analysis among other methods. They elaborated on the notion that the central placement of the cemetery in urban space must have been important from an early date. This aspect is supported by ethnographic data about the situated activities, which associate tombs with public gatherings and rituals (El-Zein 1974; El Amrousi 2012) and with oral histories of people's movement along the coast (ElZein 1974). What follows is a comparative review which develops the notion that we could explain the meaning of pillar tombs by primarily understanding their role on sites where they represent integrative components of urban built environment, as a type of context in which pillar tomb can be found in the most numerous and earliest examples.

\section{Visibility}

'Visibility' as referred to here as one of the representations of monumentality (Moore 2005: 86-88). The height of pillar tombs is the most prominent aspect of their size and the most relevant in an urban environment where it makes them much more visible from a greater distance or over the walls 
of buildings. Their exterior visual impact somewhat stands in opposition to the general guidance of Islam, which promotes humble burials (Gensheimer 2012: 109). Although in many Muslim cultures monumentality is tolerated for the tombs of holy men, martyrs and leaders (Abungu 1994; Lapidus 2012), the Swahili accent on monumental tombs directly in urban contexts supports the idea that it had more complex meaning apart from representing a place of spiritual power. This is further supported by the fact that the superstructures of tombs could have been built sometime after the burial (Fleisher and Wynne-Jones 2012), and so were unrelated to the event of funeral, although the future building of a tomb at a certain place must have been planned when the deceased was buried. It has been suggested many times that the purpose of the monumentality of Swahili tombs was commemoration of ancestors (Wilson 1979), a practice associated with processions, public events (Fleisher 2013) and display of allegiance and power (Horton 1996), similar to ritual re-visiting of monumental tombs in other Muslim communities.

Monumentality in the unique form of pillar tombs and their popularity demonstrated by the fact that on the northern Kenya coast almost 25\% of recorded stone tombs are pillar tombs (calculation based on Wilson 1978), might be explained within the context of the built environment. As the tombs added to the rapidly developing townscapes, it might have been that only a pillar could make them visible from a distance. The visual dominance of the height of pillars, towering over people and most buildings must have played an important role. If we consider pillar tombs that were positioned directly next to buildings and where access to them for people apart from the occupants might have been limited (e.g. at the Gede palace complex), the visibility and awareness of the tomb's presence rather than physical access to that monument might have conveyed varied messages depending on spatial and situational context. At times, pillar tombs might have been understood as very private spaces for the relatives of the deceased, while at other times it might have influenced power negotiations within the town as well as making an impression on people from outside the city, such as visitors and traders.

The aspect of visibility of pillar tombs has already been highlighted by some researchers, who, however, explained it as motivated by practical goals, mainly navigation and way-finding. There are a number of sites where tombs were built on natural elevated ground above settlement as at Dondo (Wilson 1978: 107-110, 1979: 36) and Shaka (Wilson 1978: 60), both in Kenya. It has been suggested that at some of these locations where pillar tombs might have been visible from the sea, they served navigation purposes, such as at Ras Kiambone and Myaandi in Somalia (Sanseverino 1983). The dominant Mbaraki pillar next to Kilindini mosque in Mombasa is also associated with tombs. It is $14 \mathrm{~m}$ high and the only hollow example 
among Swahili pillars (Sassoon 1982). The purpose for which it was built remains quite obscure, although we know it was not meant to be climbed as a tower or minaret (Sassoon 1982; Giles 1987). In South Kenya, tombs were known as alama, which means a banner (Krapf 1882: 7), possibly making a clearly visible statement of group allegiance. More recently, it has been argued that some parts of Swahili towns, where a cemetery stood near a potential landing or port, the direct access to mortuary spaces from the sea signifies that they might have been a destination of their own (Fleisher 2013: 273).

However, tombs with pillars in urban context were built both on hills and on lower ground, in a group or in isolation, and on all types of sites with good, bad or no anchorage-as at Gede and Ishakani in Kenya (Wilson 1978: 2-19). Yet, a general cultural role which would explain the widespread tradition in their possible placement in urban context and high visibility must have existed, because they were universally recognisable along the whole coast, built to be viewed and must have been readily interpreted in a consistent manner. Pillar tombs can be understood as a type of cultural marker, which in some places was meant to communicate to a wider, more distant audience, visible not just from some houses or parts of the city but even from the sea. It might have testified to relationships between the living and their locally buried, and hence long-established, ancestors. It seems logical, therefore, that the combination of a mortuary monument related to ancestry and a demarcation of land in the form of a pillar could represent an important component in place-making, but their high visibility oriented towards town residents as well as to the outside world suggests that they were much more active in the process of creating distinctive cultural identity along the coast then it has been recognised so far.

\section{Placement Within Townscapes and Identity}

The results of a number of ethnographic studies from the 19th century onwards suggest that Swahili identity has been considerably fluid, based on personal and group affiliations and allegiances, which are not based on place of birth, but by shared residence, i.e. on the fact that people share their lives as coastal dwellers (Topan 2006). Furthermore, the broader everyday reality of life on the coast, which was characterised by constant encounters with and references to other cultures from around the Indian Ocean, especially from the 13th century when these contacts intensified, a stronger need for assertions of group identity must have been felt by people wanting to stress the distinctiveness of their hometowns on the coast. Abrams (1989: 62) argued that public architecture of a monumental char- 
acter is one of the most effective means for providing group identity against 'increasing linguistic, ethnic, social and economic heterogeneity'. Elsewhere in the Indian Ocean in the 19th century, as described in detail by Ho (2006: 230-231), people have been known to relate tombs with homeland and identity. In other words, the highly visible pillar tombs were relevant as an everyday environmental backdrop to movement and encounters taking place around the town. The great variety in the external appearance and decoration of pillar tombs likely further promoted their memorability. This explains why on sites where more pillar tombs were gradually added, their builders tended to opt for designs that differed from those already present in the town. The dispersed rather than concentrated placement of pillar tombs within towns that feature multiple examples of pillar tombs might have ensured interaction between parts of society for whom direct interaction was normally rare and structurally uneven, such as the rich and the poor. Generally, similar mnemonics greatly add to certain social cohesiveness allowing for future cooperation within the community (Cox et al. 1999).

This concept of identity and way of life, if it extends further back in history, might be reflected in past burial customs, such as the division of graves into clusters on a cemetery at Shanga that might have represented individual clans (Horton 1996: 75) or possible public performance associated with later additional interments in tombs at Songo Mnara (Fleisher 2013). Furthermore, in an enterprising society these practices might be used for actively 'creating' kinsmen, or tying together more distant relatives (who could have come from a different town) as people buried together now having local ancestors. Diverse patronage and allegiance ties are often (un)made around funeral events in Africa (Jindra and Noret 2011: 24), and prominent pillar tomb in particular might have added a permanent material reminder of these. The pillar tombs hence might have served as a very effective spatial reference point within local townscapes on which to build social relationships.

\section{Thresholds and Displays}

Pillar tombs in their design reference many features encountered on houses and mosques. Since the 1990s, decorative architectural features have been considered in relation to the concept of privacy in Swahili society, in part under the influence of the so-called house-power model based on ethnographic studies of the Swahili house (Donley 1982; Donley-Reid 1987, 1990) and the potential implications of the 'typical' layout of a Swahili house. 
Although this model proved problematic (for an overview and critique see Fleisher 2015), given the spatial organisation of rooms in Swahili houses allowing gradated access and often combined with an alignment of doorways, it seems beyond doubt that thresholds, as well as the difference between visual and physical access to places played a role in both the recent and more distant past. This can be demonstrated on the example of zidaka or vidaka, which is the term for a series of niches on the back wall of the innermost room of certain Swahili houses used for display of valuables (Figure 5) that, however, thanks to the alignment of doorways, are visible from the front room of the house. Looking at the decoration of tombs we may note many cross-references to the niches of the zidaka used in houses, such as on the tombs at Siyu, Kenya (Figure 6). If the use of niches had the same meaning in both contexts, the tombs might have been seen as very private, yet meant for display. The tomb itself (and the burial) is positioned actually behind the decorative niches on the tomb wall and so in a space, which the houses do not feature, as if the deceased was buried in yet another back room, ultimately the most private space.

The decoration of doorways also brings about references to the tombs. For example, actual doorways as well as the symbolic doorways or decorative panelling of tombs both feature series of recessed surfaces (Wilson and Omar 1997). The decorative niches used on doorways (Figure 7) and those

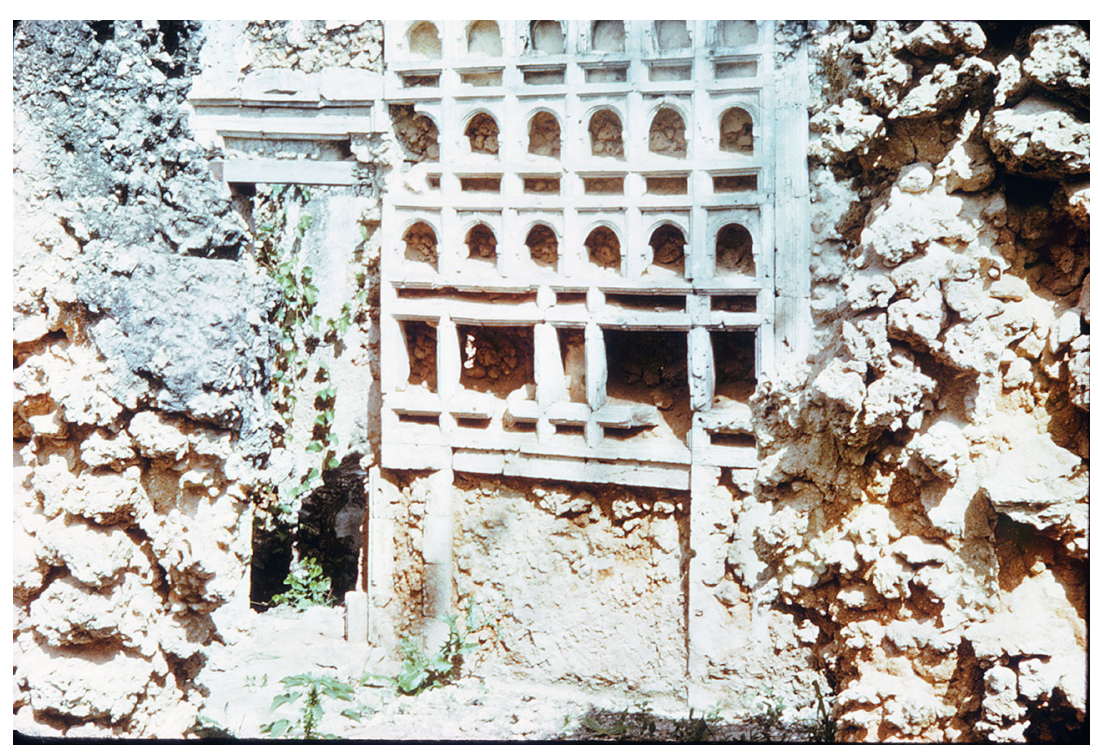

Figure 5. Zidaka in an archaeological context, house near Jambeni, Pate, November 1965. Photograph Neville Chittick @ BIEA, reproduced with permission 


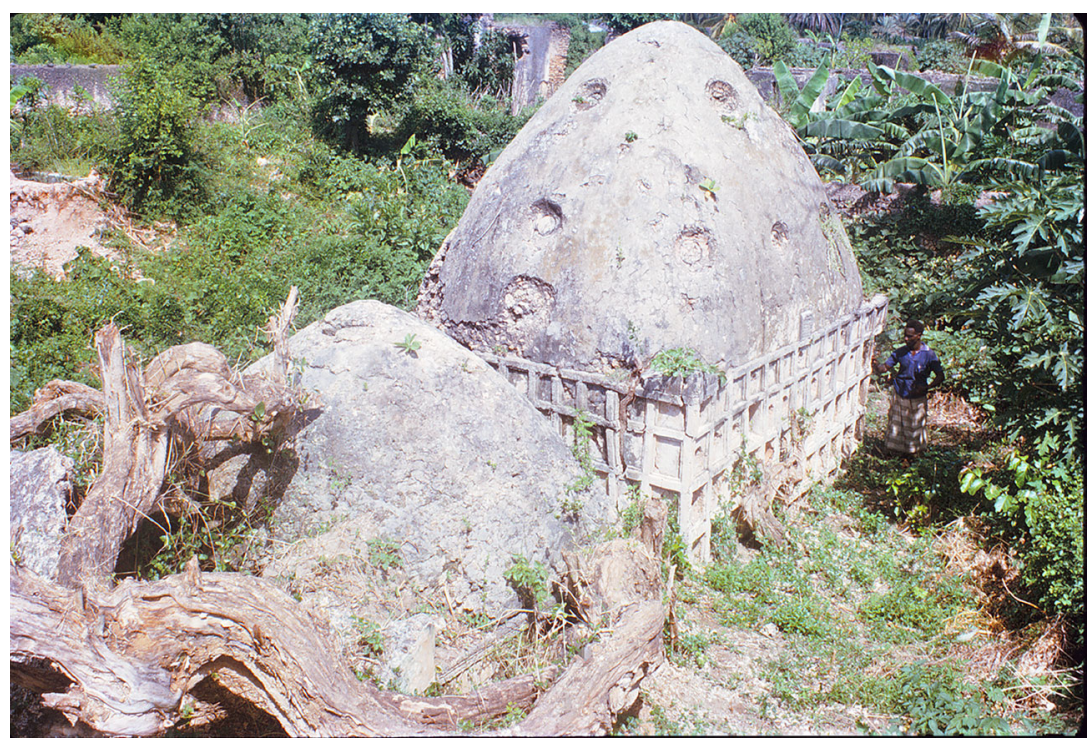

Figure 6. Domed tomb with niches, Siyu, opposite Friday mosque, November 1966. Photograph Neville Chittick (C) BIEA, reproduced with permission

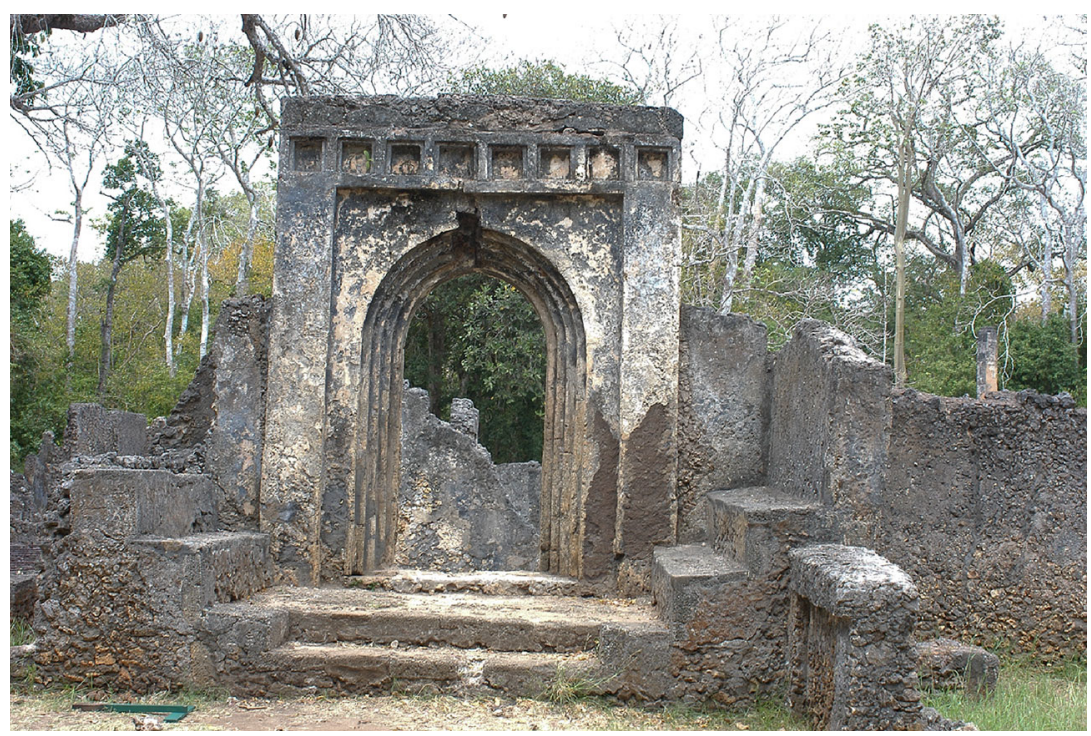

Figure 7. Monumental doorway-entrance to the so-called Palace of Gede, Kenya-showing the use of decorative niches. (c) The Zamani Project, reproduced with permission 
used on tombs (e.g. at Ungwana) are usually too shallow to have served any practical purpose for display of items as in the case with zidaka (Kirkman 1966), but their presence as such brings about the notion that in all three contexts we encounter a threshold.

Gensheimer (2012: 112) argued that the tombs might have been literally 'houses for the dead' and that, building on Donley-Reid's ethnographic house-power model, the use of features such as zidaka might have been meant to suggest the purity of mortuary architecture. However, we need to consider the aspect of time it took to build both the tombs and the houses. It is known ethnographically that the Swahili still invest a lot of time and planning in the building of their houses, considering it a process that never really ends (Verne 2012). Just like houses, the appearance of tombs could have been continually altered, maybe in association with successive commemoration rituals. So, it is likely that the pillar tombs were one of the material reference points in promoting social rules associated with demarcating thresholds, and structuring visual and physical access.

\section{Conclusions}

Within the wider Islamic world, the central location or monumentality of tombs are not unique to the Swahili. However, pillar tombs in their form and context are found only on the Swahili coast and represent an innovative use of mortuary architecture in an urban setting, regardless of whether the inspiration for pillars might or might not have been foreign. The exceptionally good visibility of the pillars within the urban landscape made them recognisable enough along the whole coast by all those familiar with life in Swahili towns and perceptive to their cultural references about expected behaviour and meaning.

Yet, upon closer inspection the pillar tombs were also sufficiently varied in detail to be identifiable and individually unique. They might have been durable and highly visible assertions of social power and wealth that took generations to achieve. Representing an addition to the evolving Swahili built environment and rapidly becoming widespread from around the 13th century $\mathrm{AD}$, they can be interpreted as material statements of coastal cultural values that were beginning to be recognised as universal and publicly displayed. They probably served as mortuary infrastructure active in creating Swahili identity, which was locally diverse as well as shared along the whole coast. Pillar tombs are also products of a globalised cosmopolitan culture, demonstrating the use of ideas and items that might not be indigenous but acquired a deeply local meaning.

In ethnographic studies, the Swahili have been described as a society for which travel and trading connections are of paramount importance for 
identity and self-identification (Le Guennec-Coppens 2002), alongside home-making processes including the ability to interpret spatial reference points and to understand proper use of certain spaces and buildings (Verne 2012: 198-200). The spatial distribution and form of Swahili pillar tombs asserts the ethnographic notion of fluid identity of the Swahili, when the society regards its members as characterised not exclusively by place of birth, but also by their dwelling in the Swahili region and their urbanity. As 'objects, people and ideas make places travel' (Verne 2012: 238), so people from along the coast who travelled among the towns in the past to trade, who understood the memory and messages conveyed by the built environment, might have considered themselves Swahili. Having made enough money and established relations with important people and social groups, individuals and families might have started to sponsor grander building projects and help (re)define the social practices through forming the spaces in which they took place.

Pillar tombs shared a number of features with other types of stone architecture, and so further anchored the importance of thresholds as well as display of influence and wealth in the built environment. Their popularity along the coast, inclusion as a type of mortuary infrastructure among the buildings for the living on a number of sites and the variety in their design wherever they appeared in more examples suggest, that they created reference points for social assertions of shared identity in a society that has never formally united. At the same time, they allowed for social competition to be enacted following the notion that a social contract emerged in Swahili society around the 13 th-15th century that wealth of any kind, in material objects or in claims of ancestry, social status, rights of residence and spiritual protection need to be displayed to matter.

\section{Acknowledgements}

This paper was written with the support of the author's Marie Skłodowska-Curie Actions Individual Global Fellowship (No. 656767 -TEMPEA). Hans Rüther and Ralph Schroeder from the Zamani Project (University of Cape Town) kindly shared with me their recent photographs of the site of Gede. Thanks are also due to the British Institute in Eastern Africa for permission to reproduce a series of stone tombs from their photographic archives. I am grateful to Paul Lane and Stephanie Wynne-Jones for providing comments on earlier drafts of this paper. 
Open Access This article is distributed under the terms of the Creative Commons Attribution 4.0 International License (http://creativecommons. org/licenses/by/4.0/), which permits unrestricted use, distribution, and reproduction in any medium, provided you give appropriate credit to the original author(s) and the source, provide a link to the Creative Commons license, and indicate if changes were made.

\section{References}

Abrams, E.

(1989). Architecture and energy: An evolutionary perspective. In M. B. Schiffer (Ed.), Archaeological method and theory (pp. 47-87). Tucson: University of Arizona Press.

Abungu, G. H. O.

(1994). Islam on the Kenyan coast, faithful versus unfaithful: an overview of Kenyan coastal sacred sites. In D. L. Carmichael, J. Hubert, B. Reeves, \& A. Schanche (Eds.), Sacred sites, sacred places (pp. 152-162). London: Routledge.

Allen, J. D. V.

(1974). Swahili culture reconsidered. Azania: Archaeological Research in Africa, 9(1), 105-138.

Beaujard, P.

(2012). Les mondes de l'océan Indien (Vol. 1). Paris: Armand Colin.

Bloch, M.

(1971). Placing the dead: Tombs, ancestral villages and kinship organization in Madagascar. London: Seminar Press.

Breen, C., \& Lane, P.

(2003). Archaeological approaches to East Africa's changing seascapes. World Archaeology, 35(3), 469-489.

Chami, F.

(2002). The excavations of Kaole ruins. In F. Chami \& G. Pwiti (Eds.), Southern Africa and the Swahili world (pp. 25-49). Dar es Salaam: Dar es Salaam University Press.

Chittick, H. N.

(1963). Kilwa and the Arab settlement of the East African coast. The Journal of African History, 4(2), 179-190.

(1967). Discoveries in the Lamu Archipelago. Azania: Archaeological Research in Africa, 2(1), 37-67.

(1970). Relics of the past in the region of Dar es Salaam. Tanzania Notes and Records, 71, 65-68. 
(1974). Kilwa: An Islamic trading city on the East African coast. Nairobi: British Institute in Eastern Africa.

(1982). Medieval Mogadishu. Paideuma, 28, 45-62.

(1984). Manda: Excavations at an island port on the Kenya coast. Nairobi: British Institute in Eastern Africa.

Cox, S. J., Sluckin, T. J., \& Steele, J.

(1999). Group size, memory and interaction rate in the evolution of cooperation. Current Anthropology, 40(3), 369-377.

Crossland, Z.

(2001). Time and the ancestors: Landscape survey in the Andratsay region of Madagascar. Antiquity, 75, 825-836.

Davies, M. I. J.

(2013). Stone cairns across eastern Africa: A critical review. Azania: Archaeological Research in Africa, 48(2), 218-240.

Donley, L.

(1982). House Power: Swahili space and symbolic markers. In I. Hodder (Ed.), Symbolic and structural archaeology (pp. 63-73). Cambridge: Cambridge University Press.

Donley-Reid, L.

(1987). Life in the Swahili town house reveals the symbolic meaning of spaces and artefact assemblages. African Archaeological Review, 5, 181-192.

(1990). A structuring structure: The Swahili house. In S. Kent (Ed.), Domestic architecture and the use of space (pp. 114-126). Cambridge: Cambridge University Press.

Edwards, D.

(2013). African perspectives on death, burial, and mortuary archaeology. In S. Tarlow \& L. N. Stutz (Eds.), The Oxford handbook of the archaeology of death and burial (pp. 209-226). Oxford: Oxford University Press.

El Amrousi, M.

(2012). Imperial sanctuaries: Arab urban enclaves on the East African coast. In F. Demissie (Ed.), Colonial architecture and urbanism in Africa: Intertwined and contested histories (pp. 67-83). Farnham: Ashgate.

El-Zein, A. H. M.

(1974). The sacred meadows: a structural analysis of religious symbolism in an East African town. Evanston: Northwestern University Press.

El-Zein, I. S.

(2010). Qasr Wad Nimeiri and its qubbas. Sudan and Nubia, 14, 91-95. 
Finlay, R.

(1998). The pilgrim art: The culture of porcelain in world history. Journal of World History, 9(2), 141-187.

Fleisher, J.

(2013). Performance, monumentality and the 'built exterior' on the eastern African Swahili coast. Azania: Archaeological Research in Africa, 48(2), 263281.

(2015). Situating the Swahili house. In S. Wynne-Jones \& J. B. Fleisher (Eds.), Theory in Africa, Africa in theory: Locating meaning in archaeology (pp. 72-88). New York: Routledge.

Fleisher, J., Lane, P., LaViolette, A., Horton, M., Pollard, E., Morales, E. Q., et al.

(2015). When did the Swahili become maritime? American Anthropologist, $117(1), 100-115$.

Fleisher, J., \& LaViolette, A.

(1999). Elusive wattle-and-daub: Finding the hidden majority in the archaeology of the Swahili. Azania: Archaeological Research in Africa, 34(1), 87-108.

Fleisher, J., \& Wynne-Jones, S.

(2012). Finding meaning in ancient Swahili spatial practices. African Archaeological Review, 29(2), 171-207.

Freeman-Grenville, G. S. P.

(1962). The East African coast; select documents from the first to the earlier nineteenth century. Oxford: Clarendon Press.

Garlake, P. S.

(1966). The early Islamic architecture of the East African coast. Nairobi: Oxford University Press.

Gensheimer, T. R.

(2012). Monumental tomb architecture of the medieval Swahili coast. Buildings and Landscapes: Journal of the Vernacular Architecture Forum, 19(1), $107-114$.

Gieryn, T. F.

(2002). What buildings do? Theory and Society, 31, 35-74.

Giles, L. L.

(1987). Mbaraki Pillar and its spirits. Kenya Past and Present, 19, 44-49.

Glassman, J.

(1995). Feasts and riot: Revelry, rebellion, and popular consciousness on the Swahili Coast, 1856-1888. London: James Currey.

Grillo, K. M., \& Hildebrand, E. A.

(2013). The context of early megalithic architecture in eastern Africa: The Turkana Basin c. 5000-4000 BP. Azania: Archaeological Research in Africa, 48(2), 193-217. 
Hildebrand, E. A.

(2013). Is monumentality in the eye of the beholder? Lessons from constructed spaces in Africa. Azania: Archaeological Research in Africa, 48(2), 155172.

Hinkel, F. W.

(1992). The archaeological map of the Sudan VI. The area of the Red Sea coast and northern Ethiopia frontier. Berlin: Akademie-Verlag.

Ho, E.

(2006). The graves of Tarim: genealogy and mobility across the Indian Ocean. Berkeley: University of California Press.

Horton, M.

(1996). Shanga: The archaeology of a Muslim trading community on the coast of East Africa. London: British Institute in Eastern Africa.

Horton, M., \& Clark, C. M.

(1985). Archaeological survey of Zanzibar. Azania: Archaeological Research in Africa, 20(1), 167-171.

Horton, M., \& Middleton, J.

(2000). The Swahili: The Swahili: The social landscape of a mercantile society. Oxford: Blackwell.

Insoll, $\mathrm{T}$.

(2003). The archaeology of Islam in sub-Saharan Africa. Cambridge: Cambridge University Press.

Jindra, M., \& Noret, J. I.

(2011). African burials and sociocultural change. A review of momentuous transformations across a continent. In M. Jindra \& J. I. Noret (Eds.), Funerals in Africa: Explorations of a social phenomenon (pp. 16-40). New York: Berghahn Books.

Kirkman, J. S.

(1952). The excavations at Kilepwa: An introduction to the medieval archaeology of the Kenya Coast. The Antiquaries Journal, 32(3-4), 168-184.

(1957). Historical archaeology in Kenya 1948-1956. Antiquaries Journal, 37, 1629.

(1958). Mnarani of Kilifi: The mosques and tombs. Ars Orientalis, 3, 95-112.

(1960). The tomb of the dated inscription at Gedi. Royal Anthropological Institute Occasional Publication No. 14.

(1963). Gedi, the palace. The Hague: Mouton.

(1964). Men and monuments on the East African coast. London: Lutterworth.

(1966). Ungwana on the Tana. The Hague: Mouton. 
(1974). Gedi-A late Mediaeval city of the Swahili Sub-Arab culture of the East African coast. In Proceedings of the seminar for Arabian studies 4 (Proceedings of the seventh Seminar for Arabian Studies held at The Middle East Centre, Cambridge on 28th and 29th June, 1973) (pp. 97-104).

(1975). Some conclusions from archaeological excavations on the coast of Kenya 1948-1966. In H. N. Chittick \& R. I. Rotberg (Eds.), East Africa and the Orient: Cultural syntheses in pre-colonial times (pp. 226-247). London: Holmes and Heier.

Krapf, J. L.

(1882). A dictionary of the Suahili language. London: Trübner and Co.

Kuban, D.

(1985). Muslim religious architecture. Part II: Development of religious architecture in later period. Leiden: Brill.

Kusimba, C. M.

(1993). The archaeology and ethnography of iron metallurgy on the Kenya Coast. Ph.D. dissertation, Bryn Mawr College, Pennsylvania.

(1999a). The rise and fall of Swahili states. Walnut Creek: AltaMira Press.

(1999b). Material symbols among the precolonial Swahili of the East African coast. In J. E. Robb (Ed.), Material symbols: Culture and economy in prehistory (pp. 318-341). Carbondale: Southern Illinois University.

Kusimba, C. M., \& Kusimba, S. B.

(2003). East African archaeology: Foragers, potters, smiths, and traders. Philadelphia: University of Pennsylvania Museum.

Lapidus, I. M.

(2012). A global history of pre-modern Islamic societies. Cambridge: Cambridge University Press.

LaViolette, A.

(2008). Swahili cosmopolitanism in Africa and the Indian Ocean world, A.D. 600-1500. Archaeologies: Journal of the World Archaeological Congress, 4, $24-49$.

Le Guennec-Coppens, F.

(2002). Les Swahili: una singularité anthropologique en afrique de l'est. Journal des africanistes, 72, 5-70.

Lewcock, R.

(1976). Architectural connections between African and parts of the Indian Ocean littoral. Art and Archaeology Research Papers, 9, 16-17.

McHugh, N.

(2016). Historical perspectives on the domed shrine in the Nilotic Sudan. In A. Hanoum (Ed.), Practicing Sufism: Sufi politics and performance in Africa (pp. 105-130). Abingdon: Routledege. 
Meier, S. P.

(2016). Stories of stone. The transformation and reinvention of Swahili coast pillar tombs. In J. Beardsley (Ed.), Cultural landscape heritage in Sub-Saharan Africa (pp. 139-156). Washington, D.C.: Dumbarton Oaks Research Library and Collection.

Milwright, M.

(2010). An introduction to Islamic archaeology. Edinburgh: Edinburgh University Press.

Mire, S.

(2015). Wagar, fertility and phallic stelae: Cushitic sky-god belief and the site of Saint Aw-Barkhadle, Somaliland. African Archaeological Review, 32(1), 93-109.

Moore, J.

(2005). Cultural landscapes in the ancient andes: Archaeologies of place. Gainesville: University Press of Florida.

Mutoro, H. W.

(1994). The Mijikenda Kaya as a sacred site. In D. L. Carmichael, J. Hubert, B. Reeves, \& A. Schanche (Eds.), Sacred sites, sacred places (pp. 132-139). London: Routledge.

Navarro, J., \& Jiménez, P.

(2007). Evolution of Andalusi urban landscape: From the dispersed to the saturated medina. In G. D. Anderson \& M. Rosser-Owen (Eds.), Revisiting al-Andalus: Perspectives on the material culture of islamic Iberia and beyond (pp. 115-142). Boston: Brill.

Pawlowicz, M.

(2012). Modelling the Swahili past: The archaeology of Mikindani in southern coastal Tanzania. Azania: Archaeological Research in Africa, 47(4), 488-508.

Pearson, M. N.

(1998). Port cities and intruders: The Swahili Coast, India, and Portugal in the early modern era. Baltimore: Johns Hopkins University Press.

Phillipson, D. W.

(2003). Aksum: An archaeological introduction and guide. Azania: Archaeological Research in Africa, 38, 1-68.

Pollard, E., Fleisher, J., \& Wynne-Jones, S.

(2012). Beyond the stone town: Maritime architecture at fourteenth-fifteenth century Songo Mnara, Tanzania. Journal of Maritime Archaeology, 7(1), $43-62$.

Pouwels, R. L.

(1987). Horn and crescent. Cultural changes and traditional Islam on the East African coast, 800-1900. Cambridge: Cambridge University Press. 
Sanseverino, H. C.

(1983). Archaeological remains on the southern Somali coast. Azania: Archaeological Research in Africa, 18(1), 151-164.

Sassoon, H.

(1966). Guide to the ruins at Kunduchi. Dar es Salaam: Ministry of Community Development and National Culture.

(1980). The coastal town of Jumba la Mtwana. Kenya Past and Present, 12, 2-14.

(1982). The mosque and pillar at Mbaraki: A contribution to the history of Mombasa island. Azania: Archaeological Research in Africa, 17(1), 79-97.

Sheriff, A.

(1987). Slaves, spices, and ivory in Zanzibar: Integration of an East African commercial empire into the world economy, 1770-1873. London: J. Currey.

(2006). Between two worlds. In R. Loimeier \& R. D. Seesemann (Eds.), The global worlds of the Swahili: Interfaces of Islam, identity and space in 19th and 20th-century East Africa (pp. 15-30). Berlin: Lit Verlag.

Sinclair, P., \& Håkansson, T.

(2000). The Swahili city-state culture. In M. H. Hansen (Ed.), A comparative study of thirty city-state cultures: An investigation (pp. 463-482). Copenhagen: The Royal Danish Academy of Sciences and Letters.

Spear, T. T.

(1981). Kenya's past: An introduction to historical method in Africa. London: Longman.

Topan, F.

(2006). From coastal to global. The erosion of the Swahili "paradox". In R. Loimeier \& R. D. Seesemann (Eds.), The global worlds of the Swahili: Interfaces of Islam, identity and space in 19th and 20th-century East Africa (pp. 55-66). Berlin: Lit Verlag.

Trigger, B. G.

(1990). Monumental architecture: A thermodynamic explanation of symbolic behaviour. World Archaeology, 22(2), 119-132.

Udvardy, M. L., Giles, L. L., \& Mitsanze, J. B.

(2003). The transatlantic trade in African ancestors: Mijikenda memorial statues (vigango) and the ethics of collecting and curating non-Western cultural property. American Anthropologist, 105(3), 566-580.

Verne, J.

(2012). Living translocality: Space, culture and economy in contemporary Swahili trade. Stuttgart: Franz Steiner Verlag.

Vernet, T.

(2015). East African travelers and traders in the Indian Ocean: Swahili Ships, Swahili mobilities ca. 1500-1800. In M. Pearson (Ed.), Trade, circula- 
tion, and flow in the Indian Ocean world (pp. 167-202). Basingstoke: Palgrave Macmillan.

Walz, J. R.

(2010). Route to a regional past: an archaeology of the lower Pangani (Ruvu) basin, Tanzania, 500-1900 CE. Ph.D. dissertation, University of Florida.

Wilding, R.

(1988). Panels, pillars, and posterity: ancient tombs on the north Kenyan coast. A preliminary study, Mombasa, Fort Jesus Occasional Papers No.6.

Wilson, T. H.

(1978). The monumental architecture and archaeology north of the Tana River. Nairobi: National Museums of Kenya.

(1978/1979). Takwa: An ancient Swahili settlement of the Lamu archipelago. Nairobi: Kenya Museum Society.

(1979). Swahili funerary architecture of the North Kenya coast. In J. de Vere Allen \& T. H. Wilson (Eds.), Swahili houses and tombs of the coast of Kenya (pp. 33-46). London: AARP.

(1980). The monumental architecture and archaeology of the central and southern Kenya coast. National Museums of Kenya: Nairobi.

Wilson, T. H., \& Omar, A. L.

(1997). Archaeological investigations at Pate. Azania: Archaeological Research in Africa, 32(1), 31-76.

Wynne-Jones, S.

(2016). Material culture: Consumption and materiality on the pre-colonial coast of East Africa. Oxford: Oxford University Press.

Wynne-Jones, S., \& Fleisher, J.

(2010). Archaeological investigations at Songo Mnara, Tanzania, 2009. Nyame Akuma, 73, 2-8.

(2016). The multiple territories of Swahili urban landscapes. World Archaeology, 48(3), 349-362. 